\title{
Analysis on the Construction of Logistics Management Informatization in Colleges and Universities Under the Background of Big Data
}

Jie Zhang

Guangzhou College of South China University of Technology, Guangzhou 510800, Guangdong, China. E-mail: zhangjie@gcu.udu.cn

Abstract: At present, the application of big data technology in social production and life is increasing, which not only brings new changes to modern management, but also puts forward higher requirements for the informatization construction of logistics management in colleges and universities. At the same time, it is also a new opportunity for college logistics management. Deepening the application of big data technology in college logistics management can improve the quality of logistics management quantity is of great significance, and it is also the key to realize the overall cost control of logistics management. However, presently, there are still some problems and shortcomings in the construction of logistics management informatization in relevant colleges and universities. In this regard, we need to take big data as the background and take the actual needs as the guidance to do a good job in the informatization construction of logistics management in colleges and universities, in order to promote the continuous improvement of the informatization level of logistics management, as well as the development of university management.

Keywords: Big Data; Colleges and Universities; Logistics Management; Informatization

With the rapid development of Internet and information technology, people's way of life, study and work has gained convenience. The development and application of big data and cloud computing technology have changed people's working mode, values and thinking mode. It is an inevitable trend to apply big data technology to the construction of logistics management informatization in colleges and universities. In practice, it has verified the advantages of applying big data in logistics information management of colleges and universities ${ }^{[1]}$. At present, in the informatization construction of logistics management in some colleges and universities. The lack of big data technology integration and the limited level of information development have affected the improvement of the efficiency of logistics management work in colleges and universities to a certain extent, and effective measures should be taken to solve the problems.

\section{The necessity of the application of big data technology for logistics management in colleges and universities}

In the logistics management of colleges and universities, the application of big data technology, in fact, is to promote the construction of logistics resource management system, realize resource sharing, and promote the comprehensive coverage of logistics management, in order to build a comprehensive logistics service management platform, and truly play the role of logistics work for college teachers and students through the integration of Internet, big data, cloud computing and other information technologies. In terms of the role of big data for logistics management in colleges and universities, the necessity of its application is mainly reflected in the following aspects:

\subsection{Improving the quality and efficiency of logistics management in colleges and universities}

Logistics management is one of the important management works in colleges and universities, which involves a wide

This is an open-access article distributed under the terms of the Creative Commons Attribution Non-Commercial License (http://creativecommons. org/licenses/by-nc/4.0/), which permits unrestricted non-commercial use, distribution, and reproduction in any medium, provided the original work is properly cited. 
range of aspects, with the characteristics of suddenness and scale. In this regard, relevant personnel need to respond in time so as to make correct decisions. By combining big data technology with logistics management in colleges and universities, we can effectively find out the problems in logistics management and better deal with the problems. It can also realize the close contact between logistics personnel and teachers and students, grasp the satisfaction and suggestions of teachers and students for logistics work, which plays an important role in further improving their own work, for providing personalized logistics services and improving the quality of logistics services. At the same time, it can also realize the standardization and scientific development of logistics management in this process ${ }^{[2]}$.

\subsection{It is helpful to improve the professional quality of logistics personnel in colleges and universities}

Big data is one of the emerging technologies in the current society. Building learning and management platform with the help of big data technology promotes the transformation of management mode. Through the introduction of big data technology into the later stage of information management in colleges and universities, it advances the relevant staff to better learn and master relevant technologies, improves the theoretical and practical level of logistics personnel, and promotes the continuous improvement of logistics service quality. In addition, in this process, it also effectively reduces the costs and waste of logistics management, and promote the sustainable and efficient development of logistics management.

\section{Problems in information construction of logistics management in colleges and universities}

2.1 The insufficient construction of logistics management system integrating informatization and big data

Nowadays, some colleges and universities have begun to try to strengthen the application of advanced technology such as informatization and big data in logistics management. However, in the construction of corresponding information management system, the overall logistics management system construction is insufficient with imperfection of the relevant platform construction, and lack of effective integration of information technology and technology convergence. It leads to the low level of informatization of logistics management, low degree of intelligence and automation of logistics management, as well as inefficient utilization efficiency of logistics management resources ${ }^{[3]}$.

\subsection{Lack of high-quality personnel for logistics information management}

Now, there is a shortage of high-quality logistics informatization personnel in related colleges and universities. In the recruitment of logistics personnel in colleges and universities, the threshold is generally low. The personnel are required to be good at doing physical work and have a sense of service, with relatively low wages. Therefore, the requirements for the recruitment of logistics personnel are not high, resulting in the low professional quality of the overall logistics management team, and their grasp of information technology and big data technology is limited. Thus their technical and professional level needs to be improved.

\section{Countermeasures for informatization construction of logistics management in colleges and universities under the background of big data}

\subsection{Improving the construction of logistics information platform and promoting the effective integration of big data technology}

In the context of big data, colleges and universities should learn from the operation mode of mobile e-commerce, rely on information technology, and explore a new mode of logistics information management, in order to gradually build a new direction for logistics informatization construction, that is, based on mobile client, actively making use of the school's smart campus platform, and fully learning from the current mobile e-commerce and network e-commerce operation services mode to build a "user-oriented" logistics information service system. It is necessary to actively integrate big data technology into logistics information management, and use big data thinking to strengthen management, so as to promote the effective development of logistics management, and enhance the effective use of big data in logistics management information system of colleges and universities ${ }^{[4]}$. Only by mastering efficient management methods and providing intelligent integrated service- Intelligent logistics platform, can we coordinate and promote the development. The design of the intelligent logistics platform system should be customized according to the characteristics of logistics management in colleges and universities, and be able to connect with the relevant business systems of logistics, in order to realize the information integration of logistics management, service and operation. 


\subsection{Strengthening the construction of logistics team and improving the professional level}

To promote the construction of logistics management information in colleges and universities under the background of big data, the literacy and ability of logistics management personnel are also the key. Therefore, relevant logistics personnel are required to grasp the operation process of intelligent logistics service platform in time, actively organize relevant personnel to carry out professional skills training, and focus on the development background and key points of the intelligent logistics service platform. They are also required to fully master the system operation process and make suggestions for system improvement in the internal test stage of the system. The school can assign internal test account number and password for logistics personnel, and explain the contents and operation process of online repair reporting, service supervision, apartment management and other sections in combination with the operation of the computer, so that they can combine practical work experience and brainstorm ideas to put forward constructive suggestions for system improvement.

As an important part of the construction of smart campus, the construction of intelligent logistics service platform aims to improve the ability of intelligent, information-based and diversified service for teachers and students, upgrade the scientific, refined and convenient management level of logistics, and change the existing service mode to create a first-class logistics service system. The platform will be equipped with online repair, service supervision, apartment management and other functions, providing teachers and students with convenient use, intelligent operation, efficient service and all-weather online logistics services. The training can be explained by the actual school case for operation and management, such as "intelligent logistics integration solution", "intelligent logistics big data visualization platform", "intelligent logistics service hall”, "network repair system", "service supervision system", "campus ordering system" and "reservation management system", in order to demonstrate the operation of intelligent logistics big data visualization platform situation ${ }^{[5]}$. In the training, we should combine the actual situation of logistics and the needs of various logistics support work, grasp the key points to ensure the improvement of the overall level of logistics team construction in colleges and universities, so as to promote the informatization construction of logistics management in colleges and universities and achieve ideal results.

\section{Conclusion}

In the era of big data, the logistics management information construction in colleges and universities should have the idea and consciousness of keeping pace with the times. In logistics management, we should deepen the awareness of big data, actively connect new technologies and new ideas to ensure the advanced nature of the construction of information management system. We should also timely apply the technology development results to improve the logistics management information system functions and management methods, in order to raise the efficiency of logistics management. In this paper, combined with some problems in the construction of logistics management information in colleges and universities, the specific countermeasures are pointed out, which has certain reference value for guiding the development of logistics management in colleges and universities.

\section{References}

1. Wang X, Zhang Z, Ping Y, et al. Application of intelligent management mode in university logistics managementTaking Anhui Sino Australian Vocational College of Science and Technology as an example. Anhui Science and Technology 2020; (01): 39-40.

2. Shi L, Li H. Innovation and practice of university logistics information integrated management system based on daum model. China Education Informatization 2016; (01): 63-65.

3. Wang J, Pan Q, Wang Q, et al. Concentrate and forge ahead—Documentary of reform logistics support mechanism and innovate logistics service mode of Jiangnan University. Research on University Logistics 2015; (05): 5-9.

4. Song X, Zhang L, Zhao E, et al. Practice and thinking on the standardization construction of university logistics financial informatization_- Taking the Logistics Service Group of Beijing University of Chemical Technology as an example. University Logistics Research 2018; (10): 43-46.

5. Qiang B, Tang Z, Hu Y. Practice and exploration of university logistics informatization construction in the era of big data_-Taking Nanjing Audit University as an example. Research on University Logistics 2017; (05): 32-35. 